\title{
Pożyczki od osób fizycznych jako źródło finansowania działalności w gospodarstwach indywidualnych w Polsce ${ }^{*}$
}

\section{Wstęp}

Pożyczki nieformalne od osób fizycznych występują w każdej gospodarce niezależnie od ustroju gospodarczego czy poziomu rozwoju. Mogą być istotnym źródłem finansowania działalności podmiotów gospodarczych. Ich rola jest większa w tych gospodarkach lub ich sektorach, w których obserwuje się niedorozwój innych źródeł kredytu, szczególnie bankowego. W warunkach współczesnej gospodarki rynkowej rola pożyczek od osób fizycznych jest relatywnie wyższa $w$ rolnictwie niż w innych sektorach.

W polskiej literaturze ekonomiczno-rolniczej od bardzo wielu lat zainteresowanie autorów koncentruje się na kredytach bankowych, głównie preferencyjnych. Pożyczki od osób fizycznych jako problem badawczy praktycznie nie występuja. Wydaje się, że warto wypełnić tę lukę.

Celem opracowania jest ocena roli pożyczek prywatnych jako źródła finansowania działalności gospodarstw indywidualnych w Polsce.

\section{Źródła danych i metoda badawcza}

Dane do analizy w ramach niniejszego opracowania pochodzą $\mathrm{z}$ badań ankietowych rolników indywidualnych, przeprowadzonych przy użyciu kwestionariusza dotyczącego warunków zaciągania i spłaty różnego rodzaju kredytów według źródeł. Badaniami zostały objęte gospodarstwa, które prowadziły rachunkowość rolną pod nadzorem pracowników Instytutu Ekonomiki Rolnictwa i Gospodarki Żywnościowej (IERiGŻ) i były zadłużone z tytułu kredytów prywatnych i w różnych instytucjach niebankowych na dzień 31.12.2001 r.

*Publikacja wykonana w ramach grantu SGGW 50408020011. 
W efekcie uzyskano szczegółowe informacje dotyczące kredytów prywatnych zaciagniętych przez 98 gospodarstw. Zostały one uzupełnione danymi z IERiGŻ dotyczącymi ekonomiki tych gospodarstw. Należy zaznaczyć, że zadłużenie z tytułu pożyczek od osób fizycznych jest wynikiem kredytów o różnym przeznaczeniu, w tym i konsumpcyjnych.

Drugim źródłem danych do analizy są informacje o ekonomice wszystkich gospodarstw prowadzących rachunkowość pod nadzorem IERiGŻ z lat 1995-2001.

Podstawową metodą badawczą jest metoda opisowa wykorzystująca wyniki analizy ilościowej z zastosowaniem metod statystycznych, takich jak statystyka opisowa.

W opracowaniu zgodnie z terminologią stosowaną przez IERiGŻ z pojęciem pożyczki/zadłużenia od/u osób fizycznych jest stosowany zamiennie termin kredyt/zadłużenie prywatne.

\section{Kredyt prywatny w ekonomice gospodarstw prowadzących rachunkowość pod nadzorem IERiGŻ}

Aby zbadać skalę i rolę pożyczek prywatnych w finansowaniu działalności gospodarstw indywidualnych $w$ latach 1995-2001, do oceny przyjęto trzy wskaźniki kierunkowe, tj. udział gospodarstw, które zaciagnęły w danym roku kredyt prywatny w całej grupie badanych przez IERiGŻ gospodarstw, stosunek wartości kredytów prywatnych zaciagniętych przez te gospodarstwa do: po pierwsze - wartości poniesionych przez nie nakładów z zakupu, po drugie - do wartości dokonanych przez nie produkcyjnych nakładów inwestycyjnych w danym roku (tab. 1).

\section{Tabela 1}

Kredyty prywatne w gospodarstwach prowadzących rachunkowość pod nadzorem IERiGŻ i ich rola w gospodarstwach korzystających $z$ nich $w$ latach 1995-2001

\begin{tabular}{|l|c|c|c|c|c|c|c|}
\hline Wyszczególnienie & 1995 & 1996 & 1997 & 1998 & 1999 & 2000 & 2001 \\
\hline $\begin{array}{l}\text { Gospodarstwa korzystające } \\
\text { z kredytów prywatnych w ogóle } \\
\text { gospodarstw IERiGŻ (\%) }\end{array}$ & 22,8 & 25,7 & 24,0 & 23,6 & 26,1 & 28,2 & 25,6 \\
\hline $\begin{array}{l}\text { Kredyty prywatne /nakłady } \\
\text { z zakupu (\%) }\end{array}$ & 14,4 & 18,4 & 15,2 & 20,1 & 22,6 & 14,6 & 23,0 \\
\hline $\begin{array}{l}\text { Kredyty prywatne/produkcyjne } \\
\text { nakłady inwestycyjne (\%) }\end{array}$ & 30,1 & 28,0 & 25,7 & 34,5 & 54,6 & 32,9 & 40,0 \\
\hline
\end{tabular}

Źródło: Obliczenia własne na podstawie danych IERiGŻ. 
$\mathrm{Z}$ analizy danych wynika, że w latach $1995-2001 \mathrm{z}$ kredytów prywatnych rokrocznie korzystała około jedna czwarta badanych przez IERiGŻ rolników. Jest to dość znaczna liczba, sygnalizująca wage problemu, chociaż z uwagi na charakter tego kredytu niekoniecznie świadcząca o jego dużej roli dla pożyczkobiorców. Jednak porównanie wartości kredytów z nakładami na produkcję bieżącą i inwestycje pozwala stwierdzić, że kredyty te stanowiły dla gospodarstw $\mathrm{z}$ nich korzystających istotne źródło pokrywania ich wydatków.

\section{Charakterystyka ekonomiki gospodarstw zaciągających kredyty prywatne}

Do charakterystyki badanych szczegółowo 98 gospodarstw zadłużonych $\mathrm{z}$ tytułu kredytu prywatnego na dzień $31.12 .2001 \mathrm{r}$. zastosowano podstawowe wskaźniki dotyczące: cech społeczno-demograficznych ich kierowników, potencjału produkcyjnego gospodarstw, nakładów na produkcję rolniczą, kierunków i poziomu działalności inwestycyjnej, osiąganych wyników produkcyjno-ekonomicznych oraz dochodów. Ich statystykę opisową zawiera tabela 2.

\section{Tabela 2}

Charakterystyka ankietowanych gospodarstwa zadłużonych u osób fizycznych na dzień 31.12.2001 r. na tle wszystkich gospodarstw badanych przez IERiGż

\begin{tabular}{|l|r|r|r|r|}
\hline Cecha badanej zbiorowości & \multicolumn{2}{|c|}{$\begin{array}{c}\text { Gospodarstwa zadłużo- } \\
\text { ne prywatnie }\end{array}$} & \multicolumn{2}{|c|}{$\begin{array}{r}\text { Wszystkie gospodarstwa } \\
\text { „rachunkowiczów" }\end{array}$} \\
\hline & średnia & mediana & średnia & mediana \\
\hline Wiek kierownika gospodarstwa & 43,8 & 45,0 & 45,0 & 45,0 \\
\hline UR ogółem (ha) & 25,77 & 19,16 & 29,85 & 16,49 \\
\hline Majątek rzeczowy (zł) & 481942,2 & 366127,0 & 430592,5 & 302082,3 \\
\hline Zasób siły roboczej & 3,0 & 3,0 & 2,9 & 3,0 \\
\hline Nakłady ogółem (zł) & 74552,7 & 39161,2 & 46444,8 & 20239,2 \\
\hline $\begin{array}{l}\text { Nakłady inwestycyjne produk- } \\
\text { cyjne (zł) }\end{array}$ & 27349,1 & 6115,5 & 23066,4 & 2800,0 \\
\hline $\begin{array}{l}\text { Produkcja towarowa na 1 ha } \\
\text { UR (zł) }\end{array}$ & 4343,3 & 2838,8 & 3169,5 & 2663,5 \\
\hline Dochód rolniczy (zł) & 29353,5 & 12904,2 & 30675,7 & 14764,5 \\
\hline Zadłużenie ogółem (zł) & 61103,5 & 18247 & 37858,6 & 5000,0 \\
\hline
\end{tabular}

Źródło: Obliczenia własne na podstawie danych IERiGŻ. 
$\mathrm{Z}$ analizy danych tabeli 2 wynika, że gospodarstwa, które były zadłużone $\mathrm{u}$ osób fizycznych w porównaniu ze zbiorowością wszystkich gospodarstw IERiGŻ charakteryzują się niższym o 2 lata przeciętnym wiekiem kierownika gospodarstwa. Należy jednak zauważyć, że mediana wieku w obu grupach gospodarstw jest taka sama. Przeciętne takie gospodarstwo dysponowało mniejszym o ponad 4 ha obszarem użytkowanej ziemi (własnej i obcej), ale wartość jego majątku trwałego była o $12 \%$ większa. Przeciętny zasób siły roboczej w obu grupach był bardzo zbliżony. Bardzo duża różnica między tymi grupami gospodarstw dotyczy nakładów na produkcję ogółem. W gospodarstwach zadłużonych prywatnie przeciętna ich wielkość była o $60 \%$ większa niż przeciętna wszystkich gospodarstw ,rachunkowiczów”. Nakłady inwestycyjne były również większe o $18,6 \%$. Gospodarstwa te osiagnnęły dużo lepsze, bo przeciętnie o $37 \%$ wyższe wyniki produkcyjne na 1 ha UR, ale ich dochód rolniczy był o prawie $5 \%$ mniejszy, wydaje się, że między innymi z powodu mniejszego przeciętnego obszaru. Przeciętne zadłużenie ogółem było większe o $61 \%$. Należy pamiętać, że gospodarstwa prowadzące rachunkowość rolną pod nadzorem pracowników IERiGŻ charakteryzowały się większym obszarem, ukierunkowaniem produkcji na rynek i lepszymi wynikami produkcyjno-ekonomicznymi od przeciętnego gospodarstwa rolniczego w Polsce. Tak więc przeciętne gospodarstwo $\mathrm{z}$ ankietowanej grupy gospodarstw różni się pozytywnie od przeciętnego gospodarstwa w kraju.

\section{Źródła kredytów prywatnych}

Kredyty prywatne są udzielane przez osoby fizyczne będące w różnej relacji do pożyczkobiorcy. Moga to być krewni, sąsiedzi, znajomi, przyjaciele. Specyficzną kategorią wymagającą odrębnego potraktowania są pożyczkodawcy trudniący się zawodowo udzielaniem kredytu, tzw. lichwiarze. O ile pierwsze trzy grupy pożyczkodawców udzielają kredytów kierując się motywem wzajemnej pomocy, o tyle motywem lichwiarzy jest zysk, często stosunkowo wysoki, bo osiagany przez wykorzystanie przymusowej sytuacji kredytobiorcy. Zjawisko lichwy w rolnictwie może być bardzo dotkliwe. Występuje tam, gdzie ma miejsce niedorozwój kredytów z innych źródeł, głównie kredytów bankowych. Należy przypomnieć, że spółdzielczość kredytowa w XIX wieku rozwinęła się tak szybko i z takim sukcesem między innymi jako reakcja na panoszącą się lichwę. Lichwiarze w zaborze austriackim żądali odsetek nawet w wysokości $520 \%$ [Wojciechowski 1939]. Obecnie lichwa jest problemem rolnictwa w krajach słabo rozwiniętych, aczkolwiek niektórzy autorzy widzą pozytywne aspekty funk- 
cjonowania kredytu tego rodzaju jako jedynej dla wielu najbiedniejszych rolników możliwości pozyskania niezbędnych środków [Robinson 1998].

We współczesnym rolnictwie polskim kredyty prywatne funkcjonują równolegle $\mathrm{z}$ kredytami bankowymi i w różnych instytucjach niebankowych. Ich strukturę według kredytodawców w grupie 98 ankietowanych gospodarstw prezentują dane w tabeli 3.

\section{Tabela 3}

Struktura kredytów prywatnych według źródeł w 98 badanych gospodarstwach zadłużonych na dzień 31.12.2001 r.

\begin{tabular}{|l|c|c|}
\hline Żódło kredytu & \multicolumn{2}{|c|}{ Struktura kredytów } \\
\hline Ogółem & 108 & $100 \%$ \\
\hline Rodzina & 81 & 75 \\
\hline Sąsiad & 10 & 9,2 \\
\hline Znajomy, przyjaciel & 14 & 13 \\
\hline Osoba trudniąca się pożyczkami & 0 & 0 \\
\hline Brak odpowiedzi & 3 & 2,8 \\
\hline
\end{tabular}

Źródło: Obliczenia własne na podstawie danych IERiGŻ.

Z danych zawartych w tabeli 3 wynika, że podstawowym źródłem kredytów prywatnych są krewni. Na drugim miejscu, ale z udziałem wielokrotnie niższym, są znajomi, a na trzecim sąsiedzi. Taka struktura kredytodawców wynika $\mathrm{z}$ faktu, że w kredytach prywatnych podstawową rolę odgrywa zaufanie. Są one udzielane najczęściej bez żadnego pisemnego potwierdzenia (umowy pisemnej) i bez żadnego zabezpieczenia. Dominujacy udział krewnych może świadczyć o braku wzajemnego zaufania i solidarności między członkami społeczności wiejskiej. Nie ma jej nawet wśród najbliższych sąsiadów. Jest to negatywny sygnał o więziach społecznych na wsi i źle rokujący dla innych dziedzin życia społecznego i gospodarczego, np. dla tworzenia grup producenckich czy realizowania wspólnych inicjatyw lokalnych. Charakterystyczny w wynikach, ale nie budzący zdziwienia, jest brak kredytu lichwiarskiego, co świadczy o tym, że rolnicy mają inne możliwości pozyskania potrzebnych środków finansowych i nie sa zmuszeni do korzystania z pomocy lichwiarzy. Jednak skoro w miastach powstają przedsiębiorstwa udzielające takich pożyczek i szeroko reklamują swoją działalność, to można się spodziewać, że ich klientami staną się $\mathrm{W}$ przyszłości również rolnicy. Taka struktura zadłużenia dowodzi niekomercyjnego charakteru tych kredytów. Stwierdzenie to potwierdzają warunki tych kredytów. Zdecydowana większość umów kredytowych nie przewiduje żadnego wynagrodzenia z tytułu kredytu. Tylko w $14,5 \%$ przypadków wystąpiło wynagrodzenie, w tym tylko $\mathrm{w} 4,5 \%$ wynagrodzenie pieniężne. Tak więc twierdzenie, że są one formą wzajemnej pomocy, niestety ograniczonej prawie tylko do rodziny, jest w pełni uprawnione. 


\section{Kierunki wykorzystania kredytów prywatnych zaciągniętych przez ankietowane gospodarstwa}

Kredyty prywatne, podobnie jak kredyty zaciagane w innych źródłach, mogą służyć finansowaniu realizacji różnorodnych celów związanych z konsumpcją bieżąca, zakupami trwałych środków konsumpcji, produkcją bieżącą i rozwojem gospodarstw. W tabeli 4 ukazano cele wykorzystania kredytów prywatnych w badanych 98 gospodarstwach.

\section{Tabela 4}

Struktura ilościowa i wartościowa kredytów prywatnych będących przyczyną zadłużenia badanych gospodarstw na dzień 31.12.2001 r.

\begin{tabular}{|l|c|c|c|c|}
\hline \multirow{2}{*}{ Cel kredytu } & \multicolumn{2}{|c|}{ Struktura ilościowa } & \multicolumn{2}{|c|}{$\begin{array}{c}\text { Struktura } \\
\text { wartościowa }\end{array}$} \\
\cline { 2 - 5 } & liczba & $\%$ & $\begin{array}{c}\text { wartość } \\
(z ł)\end{array}$ & $\%$ \\
\cline { 2 - 5 } & 108 & $100 \%$ & 771504 & 100 \\
\hline Zakup ziemi & 4 & 3,7 & 47100 & 3,5 \\
\hline Zakup samochodu osobowego & 9 & 8,3 & 45700 & 3,3 \\
\hline $\begin{array}{l}\text { Zakup maszyn, narzędzi rolniczych } \\
\text { íśodków transportu }\end{array}$ & 19 & 17,6 & 427100 & 31,1 \\
\hline Zakup stada podstawowego & 1 & 0,9 & 1500 & 0,1 \\
\hline $\begin{array}{l}\text { Budowa, remont i modernizacja budyn- } \\
\text { ków gospodarczych }\end{array}$ & 7 & 6,5 & 109800 & 8 \\
\hline $\begin{array}{l}\text { Budowa, remont i modernizacja budyn- } \\
\text { ków mieszkalnych }\end{array}$ & 10 & 9,3 & 107974 & 7,9 \\
\hline $\begin{array}{l}\text { Założenie i modernizacja plantacji } \\
\text { trwałych }\end{array}$ & 2 & 1,9 & 32330 & 2,4 \\
\hline $\begin{array}{l}\text { Bieżazca produkcja rolna (nawozy, środki } \\
\text { ochrony roślin, pasze) }\end{array}$ & 23 & 21,3 & 421800 & 30,7 \\
\hline $\begin{array}{l}\text { Usługi i inne cele zwiazzane z prowadze- } \\
\text { niem gospodarstwa }\end{array}$ & 11 & 10,2 & 61636 & 4,5 \\
\hline $\begin{array}{l}\text { Wyposażenie mieszkania (AGD, RTV, } \\
\text { meble i inne) }\end{array}$ & 3 & 2,7 & 19500 & 1,4 \\
\hline $\begin{array}{l}\text { Różne konsumpcyjne (inne i bez spre- } \\
\text { cyzowania) }\end{array}$ & 19 & 17,6 & 98000 & 7,1 \\
\hline
\end{tabular}

Źródło: Obliczenia własne na podstawie danych IERiGż.

Dane o przeznaczeniu kredytów wskazują, że gros kredytów, bo aż 70,4\% liczby rozpatrywanych, zaciągnięto $w$ celach związanych $\mathrm{z}$ bieżąca produkcją rolniczą lub działalnością inwestycyjną i produkcyjną. Jeżeli uwzględnimy w działalności inwestycyjnej budowę, remont i modernizację budynków mieszkalnych, to ten odsetek wzrośnie do niemalże $80 \%$. Najwięcej kredytów inwestycyjnych zaciagnęli rolnicy na zakup maszyn i narzędzi rolniczych, na dru- 
gim miejscu znalazły się kredyty związane $\mathrm{z}$ poprawą warunków mieszkaniowych, na trzecim na zakup samochodu osobowego. Najmniej kredytów prywatnych przeznaczono na założenie plantacji trwałych i na zakup stada podstawowego. Kredyty obrotowe były przeznaczane przede wszystkim na zakup środków obrotowych, chociaż zakup usług produkcyjnych i pokrycie innych wydatków związanych z prowadzeniem gospodarstwa był celem aż 10,2\% kredytów. Analiza struktury wartościowej kredytów jeszcze bardziej świadczy na rzecz produkcyjnego charakteru kredytów prywatnych, bo aż 91,5\% wartości zaciagniętych pożyczek było przeznaczonych na środki obrotowe, usługi produkcyjne i inwestycje w gospodarstwach. 56,3\% wartości kredytów wydano na inwestycje, wśród których największy udział miały maszyny i narzędzia rolnicze. $35,2 \%$ wartości kredytów to kredyty obrotowe, w ramach których pożyczki na zakup środków obrotowych, takich jak nawozy, pasze, środki ochrony roślin, przewyższają wielokrotnie te zaciagnnięte na zakup usług $i$ inne cele związane $\mathrm{z}$ prowadzeniem gospodarstwa.

Struktura ilościowa i wartościowa omawianych kredytów świadczy, że motywem zaciągania kredytów prywatnych była potrzeba sfinansowania działalności gospodarstwa rolniczego, natomiast ich znaczenie $\mathrm{w}$ finansowaniu konsumpcji było małe.

\section{Rola pożyczek od osób fizycznych w finansowaniu działalności inwestycyjnej i bieżącej ankietowanych gospodarstw}

W ankietowanej grupie gospodarstw zadłużonych $\mathrm{z}$ tytułu kredytów prywatnych rola tych kredytów w finansowaniu działalności produkcyjnej i inwestycyjnej w 2001 r. była znaczna (tab. 4).

Kredyty prywatne miały większe znaczenie $w$ finansowaniu inwestycji produkcyjnych niż w finansowaniu nakładów środków obrotowych z zakupu. Ich udział przekroczył $20 \%$ nakładów inwestycyjnych, podczas gdy udział prywatnych kredytów obrotowych $-8 \%$. W ramach prywatnych kredytów inwestycyjnych szczególnie duże znaczenie miał kredyt na zakup maszyn i narzędzi rolniczych. Około $35 \%$ nakładów na ich zakup pochodziło z kredytu prywatnego. Istotne znaczenie miał też kredyt na zakup stada podstawowego, ale należy zauważyć, że kredyt ten był zaciągnięty przez jedno gospodarstwo, a ponieważ nakłady na zakup stada $w$ badanej grupie nie były wysokie, udział tego kredytu był znaczny. 


\section{Tabela 4}

Udział kredytów prywatnych w finansowaniu dzialainości produkcyjnej badanych 98 gospodarstw indywidualnych w 2001 r. (\%)

\begin{tabular}{|l|c|}
\hline Wyszczególnienie & 2001 \\
\hline $\begin{array}{l}\text { Kredyty inwestycyjne ogółem w nakładach inwestycyjnych } \\
\text { i produkcyjnych }\end{array}$ & 20,20 \\
\hline w tym kredyt na: & 20,60 \\
\hline zakup ziemi w nakładach na zakup ziem & 14,60 \\
\hline $\begin{array}{l}\text { zakup samochodu osobowego w nakładach na zakup sa- } \\
\text { mochodów osobowych }\end{array}$ & 34,20 \\
\hline $\begin{array}{l}\text { zakup maszyn i narzędzi rolniczych i środków transportu } \\
\text { w nakładach na zakup maszyn i narzędzi rolniczych } \\
\text { i środków transportu }\end{array}$ & 25,60 \\
\hline $\begin{array}{l}\text { zakup stada podstawowego w nakładach na zakup stada } \\
\text { podstawowego }\end{array}$ & 19,60 \\
\hline $\begin{array}{l}\text { budowę, remont i modernizację budynków gospodarczych } \\
\text { w nakładach na budynki gospodarcze }\end{array}$ & 11,10 \\
\hline $\begin{array}{l}\text { budowę, remont i modernizację budynków mieszkalnych } \\
\text { w nakładach na budynki mieszkalne }\end{array}$ & 7,40 \\
\hline $\begin{array}{l}\text { założenie i modernizacja plantacji trwałych nakładach na } \\
\text { plantacje trwałe }\end{array}$ & 8,23 \\
\hline Kredyty obrotowe ogółem w nakładach z zakupu & \\
\hline
\end{tabular}

Źródło: Obliczenia własne na podstawie danych IERiGŻ.

\section{Podsumowanie}

$\mathrm{Na}$ podstawie przeprowadzonej analizy można stwierdzić, że z kredytów prywatnych korzystał rokrocznie znaczący odsetek badanych rolników. Kredyty te były przeznaczane głównie na potrzeby związane z prowadzeniem gospodarstwa rolnego. Kredyty konsumpcyjne stanowiły margines zaciagniętych kredytów. Rola analizowanych kredytów dla badanych gospodarstw w finansowaniu inwestycji i bieżącej działalności rolniczej była znaczna. Dostarczyły one środków na sfinansowanie około $20 \%$ wartości inwestycji produkcyjnych i około $10 \%$ wartości nakładów z zakupu.

\section{Literatura}

ROBINSON M.S., 1998: Microfinace: The Paradigm Shift from Credit Delivery to Sustainable Financial Intermediation. [w:] International Agricultural Development, edited by Eicher C.K., Staatz J.M., The Johns Hopkins University Press, Baltimore and London. 
WOJCIECHOWSKI S., 1939: Historia spółdzielczości polskiej do 1914 roku. Nakładem Spółdzielczego Instytutu Naukowego. Zakład Drukarski F. Wyszyński i S-ka, Warszawa.

\section{The Loans form Individuals as a Source of the Financing of the Activity of Private Farms in Poland}

\section{Abstract}

The aim of the analysis was to evaluate the role of loans granting by individuals in the financing of the agricultural activity of private farms in Poland. The investigation showed that quite large percentage of farms used this kind of credit. The share of private credits in financing of agricultural investments was about $20 \%$, in financing of working capital about $8 \%$. 